\title{
SILAS MARNER BY GEORGE ELIOT
}




\section{MACMILLAN MASTER GUIDES}

General Editor: James Gibson

Published:

JANE AUSTEN: EMMA Norman Page

ROBERT BOLT: A MAN FOR ALL SEASONS Leonard Smith EMILY BRONTË: WUTHERING HEIGHTS Hilda D. Spear GEOFFREY CHAUCER: THE PROLOGUE TO THE CANTERBURY

TALES Nigel Thomas and Richard Swan

CHARLES DICKENS: GREAT EXPECTATIONS Dennis Butts

GEORGE ELIOT: SILAS MARNER Graham Handley GEORGE ORWELL: ANIMAL FARM Jean Armstrong WILLIAM SHAKESPEARE: MACBETH David Elloway

A MIDSUMMER NIGHT'S DREAM

Kenneth Pickering

ROMEO AND JULIET Helen Morris

Forthcoming:

JANE AUSTEN: MANSFIELD PARK Richard Wirdnam PRIDE AND PREJUDICE Raymond Wilson

CHARLES DICKENS: HARD TIMES Norman Page GEORGE ELIOT: MIDDLEMARCH Graham Handley T. S. ELIOT: MURDER IN THE CATHEDRAL Paul Lapworth OLIVER GOLDSMITH: SHE STOOPS TO CONQUER Paul Ranger THOMAS HARDY: FAR FROM THE MADDING CROWD

Colin Temblett-Wood

TESS OF THE D'URBERVILLES James Gibson

CHRISTOPHER MARLOWE: DR FAUSTUS David Male

THE METAPHYSICAL POETS Joan van Emden

WILLIAM SHAKESPEARE: HAMLET Jean Brooks

TWELFTH NIGHT Edward Leeson

THE WINTER'S TALE Diana Devlin

GEORGE BERNARD SHAW: ST JOAN Leonee Ormond

R. B. SHERIDAN: THE RIVALS Jeremy Rowe

Also published by Macmillan

MACMILLAN MASTER SERIES

Mastering English Literature R. Gill

Mastering English Language S. H. Burton

Mastering English Grammar S. H. Burton 


\section{MACWILLAN MASTER EUIDES}

\section{SILAS MARNER}

\section{BY GEORRE ELIOT}

GRAHAM HANDLEY

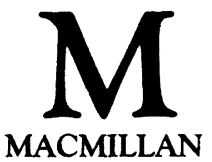


All rights reserved. No reproduction, copy or transmission of this publication may be made without written permission.

No paragraph of this publication may be reproduced, copied or transmitted save with written permission or in accordance with the provisions of the Copyright Act 1956 (as amended).

Any person who does any unauthorised act in relation to this publication may be liable to criminal prosecution and civil claims for damages.

First edition 1985

Published by

MACMILLAN EDUCATION LTD

Houndmills, Basingstoke, Hampshire RG21 2XS

and London

Companies and representatives

throughout the world

Typeset by

Tec Set, Sutton, Surrey

British Library Cataloguing in Publication Data Handley, Graham

A master guide to Silas Marner by George

Eliot.-(Macmillan master guides)

1. Eliot, George. Silas Marner

I. Title

82.3'.8 PR4670

ISBN 978-0-333-37433-7

DOI 10.1007/978-1-349-07486-0 
General editor's preface

vii

Acknowledgements

ix

1 George Eliot: life and

1.1 Life

background

1.2 Works

1

2

2 Summaries and critical

2.1 Overall summary of the plot commentary

2.2 The motto

2.3 Chapter summaries and commentary

3 Writing, chronology

3.1 Writing

and themes

3.2 Chronology

36

3.3 Themes

4 Techniques

4.1 Characterisation

43

4.2 Style and structure

5 Specimen passage and

5.1 Specimen passage

61 commentary

5.2 Commentary

6 Critical appraisals

6.1 Contemporary appraisals

6.2 Selected twentieth-century appraisals

Revision questions 


\section{GENERAL EDITOR'S PREFACE}

The aim of the Macmillan Master Guides is to help you to appreciate the book you are studying by providing information about it and by suggesting ways of reading and thinking about it which will lead to a fuller understanding. The section on the writer's life and background has been designed to illustrate those aspects of the writer's life which have influenced the work, and to place it in its personal and literary context. The summaries and critical commentary are of special importance in that each brief summary of the action is followed by an examination of the significant critical points. The space which might have been given to repetitive explanatory notes has been devoted to a detailed analysis of the kind of passage which might confront you in an examination. Literary criticism is concerned with both the broader aspects of the work being studied and with its detail. The ideas which meet us in reading a great work of literature, and their relevance to us today, are an essential part of our study, and our Guides look at the thought of their subject in some detail. But just as essential is the craft with which the writer has constructed his work of art, and this is considered under several technical headings - characterisation, language, style and stagecraft.

The authors of these Guides are all teachers and writers of wide experience, and they have chosen to write about books they admire and know well in the belief that they can communicate their admiration to you. But you yourself must read and know intimately the book you are studying. No one can do that for you. You should see this book as a lamp-post. Use it to shed light, not to lean against. If you know your text and know what it is saying about life, and how it says it, then you will enjoy it, and there is no better way of passing an examination in literature.

JAMES GiBSON 


\section{ACKNOWLEDGEMENTS}

All references to Silas Marner are taken from the Cabinet edition of George Eliot's works (Edinburgh and London, 1878-80), but the edition of Silas Marner edited by Q. D. Leavis (Penguin English Library, 1967) has also been used.

Cover illustration: Episode from Silas Marner by Oliver Madox Brown, courtesy of the City of Manchester Art Galleries. 